\title{
India pledges deluge of funds to water plan
}

\section{K. S. Jayaraman, New Delhi}

A court judgement and last year's dry monsoon season have injected fresh momentum into a massive water project that would integrate most of India's major waterways at a cost of more than US $\$ 100$ billion.

The project would link 37 rivers through a maze of 30 canals totalling 12,500 kilometres in length. It would involve the construction of 12 reservoirs, displacing an estimated 450,000 people and flooding 80,000 hectares of forest.

India's Supreme Court ruled late last year that the government should meet its constitutional requirement to supply clean water to each Indian citizen by 2016. After the ruling, Prime Minister Atal Behari Vajpayee pledged that the project should be undertaken on a "war footing" and completed by that year.

Now Indian scientists and engineers are preparing detailed plans to implement the project, the broad outline of which has languished at the planning stage for more than 20 years. But the scheme still faces several political obstacles at home and abroad, and some environmentalists are already attacking it.

"The idea is to transfer surplus water from Himalayan and other rivers to regions where it is scarce for drinking and agriculture," says Suresh Prabhu, an engineer and former energy minister who heads a task force set up after the court judgement to implement the project.

But the project would require most of India's states - as well as the parliament in New Delhi — to ratify a constitutional amendment transferring responsibility for water supply to the central government. And moves to take more water from two huge rivers involved in the scheme - the Ganges and the Brahmaputra - will raise problems with India's neighbour Bangladesh, which relies heavily on water from each of them (see Nature 422, 254-256; 2003).

Of the 1.9 trillion cubic metres of rainwater that pass through India's rivers in a typical year, about two-thirds flow into the sea. This water could, at least in theory, be used to bolster the subcontinent's water supply. Huge transfers of water between different river basins "may be the best way to efficiently utilize the national resource", argues Pavagada Venkata Indiresan, a project supporter and former president of the Indian National Academy of Engineering.

The proposed network would deliver up to 173 billion cubic metres of water - equivalent to a quarter of the Brahmaputra's flow - each year, enough to irrigate 35 million hectares and generate up to 34 gigawatts of electricity, according to Prabhu.

The project has found broad support, both among India's political parties and

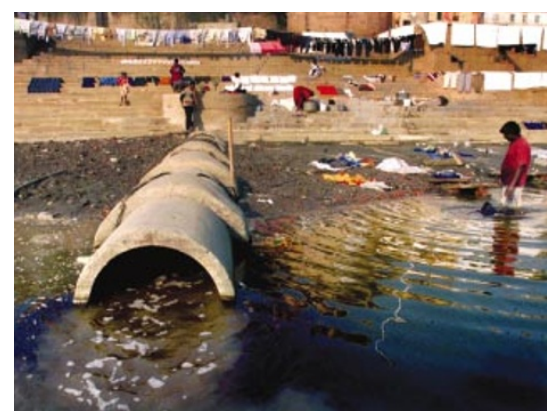

Pipe dream: India plans to harness rivers such as the Ganges to improve access to clean water.

within its scientific community. "It can result in a win-win situation for all the states," enthuses Monkombu Swaminathan, the agricultural scientist who is regarded as the father of India's green revolution.

The government has asked the Indian Institutes of Technology (IIT) to create simulations of the proposed waterway system, and has requested data from remote-sensing satellites operated by the Indian Space Research Organization. These data will be used to help to align the canals, locate suitable sites for dams, and avoid areas of likely ecological damage.

But critics, such as A. Vaidyanathan of the Madras Institute of Development Studies in Chennai, argue that the project will damage natural river ecosystems and that the government would be better off improving traditional techniques of rainwater collection and increasing the efficiency of existing irrigation systems.

"Linking the rivers is a mirage," warns Ramaswami Iyer, a former secretary of water resources, who says that the costs and political objections surrounding the project are insurmountable.

Prabhu says that the IIT will "factor the ecological fears into their simulation models" in planning the project. He also says that the project's latest estimated cost of $\$ 112$ billion can be raised through water charges, international loans and privatesector contributions. "We need $1 \%$ of the gross domestic product (GDP) every year, and once implemented, the project will boost our GDP by 5\%," he predicts.

\section{Biotech firms pin hopes on defence}

Helen Pearson, New York

Biotechnology companies - battling for survival after three years of waning investment - are turning to the US government's war on bioterrorism as a source of much-needed revenue.

The companies are eyeing initiatives such as Project BioShield, which will provide an estimated $\$ 6$ billion over ten years for the development of drugs and vaccines against agents such as anthrax and smallpox.

"It's an opportunity created by fear," says Charles Cantor, a biodefence expert and chief scientific officer at Sequenom, a genomics company based in San Diego, California.

VaxGen of Brisbane, California, suffered a blow to its long-standing objective of developing an AIDS vaccine in February, when it announced disappointing clinicaltrial results for such a vaccine (see Nature $421,877 ; 2003)$. But last October, the company was awarded $\$ 13.6$ million by the National Institute of Allergy and Infectious Diseases for trials of a vaccine against anthrax. "You have to shift with the times," says Lance Ignon, a company spokesman.

SIGA Technologies of Corvallis, Oregon, is hoping that the government will support the development of its prototype vaccines, which use harmless bacteria that are genetically engineered to produce anthrax, smallpox or plague molecules to stimulate an immune response. The company hopes to take advantage of a change made in June last year to the Food and Drug Administration's regulations. Under the new rules, vaccines against bioweapons can be approved on the basis of animal experiments alone.

Apart from generating revenue, bioterrorism projects are helping to shore up investors' confidence in some biotechnology stocks. Last month, shares in Human Genome Sciences of Rockville, Maryland, went up by about a quarter when the company announced the success of an antibody-based drug for anthrax in trials using rabbits and monkeys.

Industry analysts warn that biodefence research is unlikely to fuel a long-term revival in biotechnology investment. "I don't think it'll pull them out of a hole," says analyst Stephen Burrill of Burrill and Co., a San Francisco investment bank that specializes in biotechnology.

Part of the problem is that there is no sustainable market for biodefence drugs and vaccines after the government has stockpiled them, says Jeff Bird of venture-capital firm Sutter Hill Ventures in Palo Alto, California. And with many companies plumping for drugs and vaccines against the same diseases, they will have to compete with each other to supply the stocks. 